\title{
Suppression of Aflatoxin Production by Essential Oil and Lactobacillus rhamnosus and Molecular Detection of Aflatoxin Biosynthesis aflR Gene Expression in Aspergillus flavus
}

\author{
T. I. El-Sayed ${ }^{\#}$ and E.H., El-Dreidi* \\ Botany Department,Faculty of Science, Benha University, \\ Qalubia, Egypt and Department of Biology, Faculty of Science, \\ University of Tabuk, Tabuk, KSA.
}

\begin{abstract}
SPERGILLUS flavus produces many secondary metabolites including aflatoxin $\mathrm{B}_{1}$, the most toxic and most potent carcinogenic natural compound that causes contamination on a variety of food and feed commodities. The aim of this study was to investigate the effect of Lactobacillus rhamnosus, the essential oils anise, caraway, fennel and potassium sorbate on growth rate, and aflatoxin $\mathrm{B}_{1}$ accumulation, and also to measure expression of aflR a regulatory gene of aflatoxin biosynthesis pathway by using real time-q PCR technique. Our results indicated that all treatments exhibited potential antiaflatoxigenic and antifungal effect against A.flavus. Furthermore, $L$. rhamnosus after 7days of incubation, anise oil at concentration $100 \mu \mathrm{l} / 100 \mathrm{ml}$ medium, and potassium sorbate at concentration $4.0 \mu \mathrm{g}$ $/ 100 \mathrm{ml}$ medium at $\mathrm{pH} 6.0$ showed a lowered transcription level of aflR gene as compared to control. The results indicated that $L$. rhamnosus may be useful as a natural biocontrol and strengthens the utilization of anise oil as an ideal antimicrobial against A.flavus. Visually, the results of real time-q PCR technique for aflR gene expression indicated that it was not a useful method for diagnosis of non-aflatoxin producing strains or vise viscera.
\end{abstract}

Keywords: Aspergillus flavus, Lactobacillus rhamnosus, Anise oil, aflR gene

Aspergillus flavus produces many secondary metabolites including aflatoxins, the most toxic and most potent carcinogenic natural compound that causes aflatoxicoses and induces cancer in mammals. In addition, it is a weak and opportunistic pathogen of many crops (corn, cotton, peanuts, and tree nuts) and contaminates them with aflatoxins. This ubiquitous mold not only reduces yield of agricultural crops but decreases the quality of the harvested grains. The economic losses and the health hazards of the mycotoxins produced by spoilage fungi are of great concern to the food industry (Gray \& Bemiller, 2003 and $\mathrm{Yu}$ et al., 2005). Moreover, the diseases caused by aflatoxin consumption are loosely called aflatoxicoses. Acute aflatoxicoses results in death, chronic aflatoxicoses results in cancer, immune suppression, and other slow pathological conditions (Hsieh, 1988, Calvo et al., 2002 and Yu et al., 2005). Aflatoxin biosynthesis has

${ }^{\#}$ Corresponding author: Elfergany58@yahoo.com 
been proposed to involve at least 23 enzymatic reaction and 25 genes or open reading frames (ORFs) representing a well defined aflatoxin pathway gene cluster (Bhatnagar et al., 2003; Dutton, 1988 and Yabe \& Nakajima, 2004). Among them, the aflR gene is known to encode a major transcriptional regulator of aflatoxin biosynthesis genes (Cary et al., 2000; Woloshuk et al., 1994 and Yu et al. (1996). AFLR binds to the consensus sequence 5'-TCGN ${ }_{5}$ CGR-3' Ehrlich et al., (1999) found in the promoters of most, if not all, of the aflatoxin biosynthesis genes (Yu et al., 2004 and Bhatnagar et al., 2006). In recent years consumers have become more concerned about the processed food they buy and eat. Demands for natural, high quality preservative - free products that at the same time are safe and stable poses a challenge for the food industry, (Brul \& Coote, 1999).Considerable pressure from consumers to reduce or eliminate chemically synthesized additives in their food has led to a renewal of scientific interest in natural substances (Nychas, 1995; Tuley De Silva, 1996 and Druvefors et al., 2005). Essential oils (EOs) have been proven to be inhibitory against a wide range of food spoiling microorganism dependent upon their concentration, testing method, and active constituents (Paster et al., 1995; Lis-Balch et al., 1999 and Smith-palmer et al., 2001). Biopreservation, the control of one organism by another, has received much attention (Magnusson et al., 2003). Lactic Acid Bacteria (LAB) have a GRAS status (generally recognized as safe) status and it has been estimated that $25 \%$ of the European diet and $60 \%$ of the diet in many developing countries consist of fermented foods (Stiles, 1996). LAB are well known as starter cultures in the manufacture of dairy products (Carr et al., 2002), so LAB have several potential applications. Using LAB to control mould growth could be an interesting alternative to physical and chemical methods because these bacteria have been reported to have strong antimicrobial properties. However, the antifungal activity of lactic strains remains to be elucidated. A limited number of reports have shown that a good selection of LAB could allow the control of mould growth and improve the shelf life of many fermented products and, therefore, reduce health risks due to exposure to mycotoxins (Gourama \& Bullerman, 1995b and Dal Bello et al., 2007). El-Nezami et al. (1998) and Gratz et al, (2006) demonstrated that the probiotic Lactobacillus rhamnosus strain $\mathrm{GG}$ is able to bind the potent hepatocarcinogenic $\mathrm{B}_{1}\left(\mathrm{AFB}_{1}\right)$. Also, Bueno et al. (2006) indicated that $L$. casei CRL 431 and L. rhamnosus CRL 1224 may be useful as potential biocontrol agent against A. flavus. The aim of this study was to investigate the effect of Lactobacillus rhamnosus, some essential oils and potassium sorbate on the biosynthesis of aflatoxin and expression of aflR gene.

\section{Material and Methods}

\section{Isolation and identification of Aspergillus flavus}

Aspergillus flavus isolates were obtained from different food sources such as peanut, maize flour, corn flour and wheat flour which were randomly collected from Qalubia Governorate Egypt "winter 2011". Pure isolates of A. flavus were 
identified microscopically and cultured as previously described by Raper \& Fennell (1965), Davise (1993), Moubasher (1993), Samson (2000) and Klich (2002).

Determination of fungal growth

The mycelia were separated from yeast extract sucrose (YES) broth by filterering through filter paper (Whatman No.4) and washed three times with distilled water, dried at $70^{\circ} \mathrm{C}$ till constant weight, cooled in a desiccator and then weighed.

Production of AFs by isolated A. flavus strains

The production of AFs by A. flavus strains on liquid media (YES) was investigated according to Singh et al. (1991).

Extraction, screening and detection of aflatoxins produced by A.flavus

$50 \mathrm{ml}$ culture filtrate was extracted twice with $100 \mathrm{ml}$ chloroform in a separating funnel. The chloroform extracts (lower layer) were then filtered through anhydrous sodium sulphate, evaporated to dryness by rotary evaporator under vacuum at $40^{\circ} \mathrm{C}$ and stored at $0{ }^{\circ} \mathrm{C}$ for later chromatographic analysis.

Aflatoxins were determined using pre-coated TLC plates (Merck aluminium backed silica gel D 60 without fluorescent indicator) developed with chloroform: acetone: isopropanol: water $(88: 12: 5: 1 \mathrm{v} / \mathrm{v})$. The intensity of the aflatoxin spots was measured with a fluorodensitometer (TLD-100 Vitatron) at an excitation wavelength of $365 \mathrm{~nm}$ and emission wavelength of $443 \mathrm{~nm}$ and by HPLC method. Aflatoxin extraction and quantification were carried out using standard procedures (AOAC, 1995; 2003). AFB $1, \mathrm{AFB}_{2}, \mathrm{AFG}_{\mathrm{I}}$ and $\mathrm{AFG}_{2}$ (Sigma Chemical Co., St Louis, MO, USA) were used as reference standards. Aflatoxins $\mathrm{B}_{1}, \mathrm{~B}_{2}$ were detected as blue fluorescence and $G_{1}, G_{2}$ as yellow green fluorescence.

Quantitative estimation of aflatoxins

Aflatoxins were determined quantitatively according to AOAC (1995). Under U.V. light $(365 \mathrm{~nm})$, TLC plates were scanned using a densitometer to identify and measure sample peak areas by comparing with the standard spots. Emission was observed at $420-460 \mathrm{~nm}$.

Preparation of inoculum and growth medium

The inoculum of A. flavus isolate No.66 was obtained by growing the mold at $30{ }^{\circ} \mathrm{C}$ on slants of Sabouraud's glucose agar until well sporulated (7 days). Spores were harvested by adding $10 \mathrm{ml}$ of sterilized aqueous solution of Tween- 80 $(0.05 \% \mathrm{v} / \mathrm{v})$ to cultures and gently dislodging spores from conidiophores with an inoculation loop. The spore suspension was filtered through 4 layers of sterile cheesecloth to remove mycelial debris. The total spore count was of the suspension $\left(\approx 10^{6}-10^{7}\right.$ spore $\left.\mathrm{ml}^{-1}\right)$ was determined using a spread plate technique on Potato Dextrose Agar (PDA) plates. Lactobacillus rhamnosus was obtained from Cairo MIRCEN, Ain Shams Univesirty, Egypt. The inoculum of $L$. rhamnosus was obtained by growing isolates in $5 \mathrm{ml}$ of (MRS, $\mathrm{pH} 6.5$ ) at $37^{\circ} \mathrm{C}$ 
for $24 \mathrm{~h}$. The concentration of viable cells in the inoculum $\left(1 \times 10^{7} \mathrm{cfu} \mathrm{ml}^{-1}\right)$ was determined by plate counts on Nutrient agar (NA) medium.

\section{Detoxification effect of potassium sorbate}

Potassium sorbate salts obtained from (El-Nasr Pharmaceutical Chemical Co., Egypt) as chemical preservative was added in $0.06,0.12,0.25,0.5,1.0,2.0,4.0$, and $6.0 \mu \mathrm{g} / 100 \mathrm{ml}$ to YES medium at different $\mathrm{pHs} 4.0,6.0,8.0$, and 10.0. After inoculating with $1.0 \mathrm{ml}$ of A. flavus isolate No.66 $\left(10^{7}\right.$ spores $\left.\mathrm{ml}^{-1}\right)$ the flasks were incubated at $30^{\circ} \mathrm{C} \pm 1{ }^{\circ} \mathrm{C}$ for 7 days. Mycelium dry weight, purification and detection of aflatoxin $\mathrm{B}_{1}$ were then done as mentioned previously. Fungistatic and fungicide effects were determined according to the quantity of aflatoxin $B_{1}$ after incubation period by TLC and HPLC method (AOAC, 2003).

Detoxification effect of essential oils (EOs)

The essential oils (anise oil, caraway oil, and fennel oil) were purchased from Sekem Co. The crude oils were prepared by dissolving separately its requisite amount in $0.5 \mathrm{ml} 5 \%$ tween-20 at concentrations $(5,10,15,20,25,30,35$, 40, 50, 100, 150 and 200 oil ) $\mu \mathrm{l} / 100$ (YES) medium and then mixed with $100 \mathrm{ml}$ of YES. Flasks were inoculated aseptically with $1.0 \mathrm{ml}$ spore suspension $\left(\approx 10^{7}\right.$ spores $\mathrm{ml}^{-1}$ ) prepared in $0.1 \%$ tween-80 (Rosengaus et al., 2000) and incubated at $30^{\circ} \mathrm{C} \pm 1{ }^{\circ} \mathrm{C}$ for 7 days with triplicates. Mycelium dry weight, purification and detection of aflatoxin B1 were then done as mentioned previously. The nature of toxicity (fungistatic/fungicidal) of the essential oil was determined following Kumar et al. (2007). Fungal discs inhibited in growth in oil treated sets were re-inoculated on fresh medium after washing with distilled water and revival of their growth was observed to determine the fungicidal or fungistatic effect.

\section{Detoxification effect of Lactobacillus rhamnosus}

One $\mathrm{ml}$ spore suspension of A. flavus isolate No.66 $\left(10^{7}\right.$ spores $\left.\mathrm{m}^{-1}\right) 7$ days old culture at $30^{\circ} \mathrm{C} \pm 1{ }^{\circ} \mathrm{C}$ and $1.0 \mathrm{ml}$ Lactobacillus rhamnosus obtained from $\left(1 \times 10^{7} \mathrm{CFU} \mathrm{m}{ }^{-1}\right.$ ) (CFU: colony forming unit) grown on MRS broth for $24 \mathrm{~h}$ at $37 \pm 1^{\circ} \mathrm{C}$ were added to $100 \mathrm{ml}$ YES medium in $250 \mathrm{ml}$ Erlenmeyer flasks. Both micro-organisms were added simultaneously and were incubated for $(3,5,7,10$, 14 , and 21) days at $30^{\circ} \mathrm{C} \pm 1{ }^{\circ} \mathrm{C}$ with triplicates. At the end of incubation period, final $\mathrm{pH}$, mycelium dry weight, purification and detection of aflatoxin $\mathrm{B}_{1}$ were then done as mentioned previously.

\section{Total RNA extraction and RT-PCR}

Total RNA was extracted from A. flavus isolate No.66 grown in YES medium. Mycelia were ground in liquid $\mathrm{N}_{2}$ with sterile mortar and pestle. Total RNA was purified from the homogenized fungal mycelia using Fermentas Kit \#K0731 protocol (Chomczynski \& Sacchi, 1987) First strand cDNA was synthesized according to Fermentas Kits \#K1621 protocol (Wiame et al., 2000). aflR primer designed by Primer3 program and processed by Promega Germany. The glyceraldehydes-3phosphate dehydrogenase (GAPDH) was chosen as a system control for reverse transcription. The primer sets were aflR 5'-AAAAGTGCGATGCACCAAG-3' aflR 5' AACACTGACCCA CCTCTTCC-3' and GAPDH5'-CAAGGTCATCCA Egypt. J. Microbiol. 50 (2015) 
TGACAACTTTG-3' and reverse. GAPDH5'- GTCCACCACCC TGTTGCTGTAG-3'. Amplication of the aflr gene generated a 636 bp RT-PCR product while GAPDH gene generated a $496 \mathrm{bp} \mathrm{RT-PCR} \mathrm{product.} \mathrm{Quantitative} \mathrm{detection} \mathrm{of} \mathrm{aflR} \mathrm{expression}$ was carried out by using real-time PCR (Stratagene Modul MX 3000P) according to Fermentas Kit, \#K0221 protocol Maxima ${ }^{\circledR}$ SYBR Green/ROX qPCR Master Mix was added in $25 \mu 1$ for each reaction. Positive and negative control reactions were used to verify the results of the first strand cDNA synthesis steps. No template negative control (NTC) was important to assess for reagent contamination. The NTC reaction contained every reagent for the reverse transcription reaction except for RNA template. Data acquisition was performed during the annealing/extension step. Each PCR reaction was replicated three times and the experiment was repeated twice.

Statistical analysis

All experiments were carried out in triplicate and results represent mean \pm standard error.

\section{Result and Discussion}

Isolation and screening of A.flavus isolates produced aflatoxin

In this study, twenty- seven isolates of A.flavus from 7 food samples were isolated and screened for their ability to produce aflatoxins on yeast extract sucrose medium. Seven isolates only of A.flavus recovered in this study were aflatoxigenic. These are No.13 from peanut 1 that produced $1800 \mu \mathrm{g} / 100 \mathrm{ml}$ medium aflatoxin $\mathrm{B}_{1}$. Another two isolates of A.flavus were isolated from peanut 2. Isolate No.32 produced $800 \mu \mathrm{g} / 100 \mathrm{ml}$ medium $\mathrm{AFB}_{1}$ and isolate No. $39,1000 \mu \mathrm{g} / 100 \mathrm{ml}$ medium. Also, A.flavus isolate No.60 from corn flour produced $\mathrm{AFB}_{2}(600 \mu \mathrm{g} / 100 \mathrm{ml}$ medium $), A$. flavus isolate No.62 and from wheat flourlproduced $\mathrm{AFB}_{1} 600 \mu \mathrm{g} / 100 \mathrm{ml}$ medium. In addition, two isolate of A. flavus isolated from wheat flour1 produced aflatoxins, one of them was isolate No. 65 that produced $800 \mu \mathrm{g} / 100 \mathrm{ml}$ mediumAFB ${ }_{2}$. The other was isolate No.66 which gave the highest value of $\mathrm{AFB}_{1}, 1900 \mu \mathrm{g} / 100 \mathrm{ml}$ medium. All other isolates of A. flavus did not produce aflatoxin. This result is in agreement with those reported by many others who reported that not all A. flavus are capable of producing aflatoxins (Koehler et al., 1975 and Varma \&Verma, 1987). Among all aflatoxins, Aflatoxin $B_{1}$ is the most abundant aflatoxin and is considered to be the most toxic. Colonization of food with aflatoxigenic A. flavus is of importance because of its potential to produce aflatoxins which are potent toxic, carcinogenic, mutagenic, immunosuppressive agents (Calvo et al., 2002 and Krishnamurthy \& Shashikala, 2006). Aflatoxin not only gives rise to cases of poisoning but is also associated with cancer (liver), kwashiorkor, and growth retardation among children (Gong et al., 2004 and Tsugane, 2004). The correlation between aflatoxins and hepatocellular carcinoma was studied by Polychronaki et al. (2008).

\section{Effect of potassium sorbate}

In this study, our results in Table 1 indicated that $\mathrm{pH} 4$ the optimum $\mathrm{pH}$ value for maximum antiaflatoxigenic effect of potassium sorbate against $A$. flavus isolate No.66 then followed in descending order by $\mathrm{pH} 6>8>10$ in all concentrations used. Potassium sorbate is more effective on aflatoxin production 
more the $\mathrm{pH}$, however $\mathrm{pH}$ is more effective on growth of A. flavus. Also, at $\mathrm{pH} 4$ potassium sorbate shows fungicide effects, as well as inhibiting the production of $\mathrm{AFB}_{1}$ of the tested isolate completely at concentrations 4.0 , and $6.0 \mu \mathrm{g} / 100 \mathrm{ml}$ medium. Our results are similar to those reported by Marín et al. (2002a) who found that potassium sorbate was effective to inhibit some isolates from bakery products at $\mathrm{pH}$ 4.5. However, other studies showed that the addition of the same weak-organic acid salts in a sponge cake analogue of $\mathrm{pH} 6$ appeared to be effective only at low water activity levels (Guynot et al., 2002 and Marín et al., 2002b). Guynot et al. (2004) indicate that potassium sorbate is a suitable preserving agent to inhibit growth of xerophilic fungi in bakery products of $\mathrm{pH}$ near 4.5 regardless water activity levels. For products of slightly higher, $\mathrm{pH} 5.5$, the addition of this preservative must be combined with low water activity levels. The current accepted theory of weak acid preservative action suggests an inhibition via internal $\mathrm{pH}$ depression by directly inhibiting glycolysis enzymes (Lück, 1981 and Krebs et al., 1983). Moreover, (López-Malo et al., 2005) noticed that increasing antimicrobial concentration in the case of sodium benzoate and potassium sorbate had a dramatic effect of A.flavus germination time.

TABLE 1. Effect of potassium sorbate on aflatoxin on production and growth of $A$. flavus isolate No. 66.

\begin{tabular}{|c|c|c|c|c|c|c|c|c|c|c|c|c|}
\hline \multirow{2}{*}{$\begin{array}{l}\text { Concentration } \\
(\mu \mathrm{gg} / 100 \mathrm{ml}) \\
\text { medium }\end{array}$} & \multicolumn{4}{|c|}{ Final pH } & \multicolumn{4}{|c|}{$\begin{array}{c}\text { Average of mycelial } \\
\text { dry weight }(\mathrm{mg} / 100 \mathrm{ml})\end{array}$} & \multicolumn{4}{|c|}{$\begin{array}{c}\text { Amount of aflatoxin } \\
(\mu \mathrm{g} / 100 \mathrm{ml})\end{array}$} \\
\hline & 4 & 6 & 8 & 10 & 4 & 6 & 8 & 10 & 4 & 6 & 8 & 10 \\
\hline Control & 5.0 & 5.5 & 7.3 & 9.0 & 1.33 & 1.63 & 1.54 & 1.45 & 1600 & 1980 & 1080 & 780 \\
\hline 0.06 & \multirow{8}{*}{ 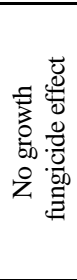 } & 5.5 & 5.5 & 5.8 & \multirow{8}{*}{ 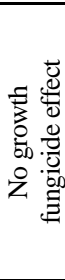 } & 1.62 & 1.51 & 1.42 & \multirow{8}{*}{ 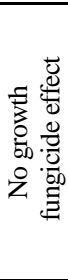 } & 1700 & 1030 & 650 \\
\hline 0.12 & & 4.5 & 5.0 & 6.0 & & 1.60 & 1.50 & 1.41 & & 1460 & 1000 & 600 \\
\hline 0.25 & & 4.8 & 5.0 & 6.0 & & 1.55 & 1.48 & 1.38 & & 1340 & 960 & 525 \\
\hline 0.5 & & 5.0 & 5.0 & 6.0 & & 1.50 & 1.43 & 1.35 & & 1300 & 560 & 485 \\
\hline 1.0 & & 5.8 & 5.6 & 6.3 & & 0.39 & 0.91 & 0.93 & & 840 & 360 & 360 \\
\hline 2.0 & & 6.0 & 6.6 & 6.7 & & 0.22 & 0.41 & 0.61 & & 440 & 200 & 100 \\
\hline 4.0 & & 7.0 & 6.8 & 7.7 & & 0.03 & 0.08 & 0.06 & & ND & 160 & $\mathrm{ND}$ \\
\hline 6.0 & & 7.0 & 7.0 & 9.0 & & 0.01 & 0.03 & 0.02 & & ND & 100 & ND \\
\hline
\end{tabular}

Effect of essential oils

Use of chemicals as preservative has led to a number of environmental and health problems due to their residual toxicity, carcinogenicity, hormonal imbalance and spermatotoxicity (Pandey, 2003 and Kumar et al., 2007). Plant essential oils have been used for hundreds of years for controlling fungus in food preservation (Bullerman et al., 1977 and Kumar et al., 2008). The results in Table 2 indicate that the essential oils tested had inhibitory effect on growth and aflatoxin accumulation by $A$.flavus. The data indicate that anise oil gave the best results with complete inhibition effect on both $\mathrm{AFB}_{1}$ and growth of the experimental organism with fungicide at lower concentration and caraway and fennel which showed lower fungitoxicity. Anise oil is thus considered the best oil used in this work. Both mycelial biomass and aflatoxin $B_{1}$ production were recorded to decrease on increasing the concentration of the oils. It was found that reduction in mycelial growth causes reduction in aflatoxin. In the present study,

Egypt. J. Microbiol. 50 (2015) 
the concentration of $150 \mu 1 / 100 \mathrm{ml}$ medium of anise, caraway or fennel inhibited $\mathrm{AFB}_{1}$ production by $A$. flavus. Similar results were reported by Kumar et al. (2008) who revealed that the same component of the oil is responsible for both activities. Moreover, these results are in agreement with the results obtained by Soliman \& Badeaa (2002) Bluma et al. (2008) and Bluma \& Etcheverry (2008) who demonstrated that the inhibitory effect of anise oil on A. flavus, A. parasiticus and aflatoxin production was higher than the remaining members of the Umbellifereae family like caraway and fennel. Also, many studies have revealed that some EOs of plants could potentially provide protection against aflatoxins especially $\mathrm{AFB}_{1}$ (Webster et al., 1996; Rasoli \& Owlia, 2005; Agar et al., 2005; Alpsoy et al., 2009 and Alpsoy, 2010). In addition, essential oils such as anise and boldus could be safely used as a preservative material on some food because they stopped fungal growth and aflatoxin accumulation $\mathrm{B}_{1}\left(\mathrm{AFB}_{1}\right)$ (Soliman \& Badeaa, 2002 and Bluma et al., 2008). The EOs composition of plants varies significantly in different genera and species. A variation in fungitoxicity of tested plant EOs against toxigenic strain of A. flavus may be due to considerable variation in EO constituents (Pina-Vaz et al., 2004 and Cavaleiro et al., 2006). The effect of anise as fungicide is much greater than that produced by the other members of the same family; the difference in anethole concentration may explain the antifungal effect observed. Also, many investigators have demonstrated the fungistatic and fungicidal effects of anise, caraway and fennel essential oils against A. flavus and A. parasiticus (Farag, 1989 and Hasan, 1994 and In addition, the physical nature of essential oils, that is, low molecular weight combined with pronounced lipophilic tendencies allow them to penetrate cell membrane more quickly than other substances (Pawar \& Thaker, 2007).

TABLE 2. Effect of essential oils on aflatoxin production and growth of $A$. flavus isolate No.66.

\begin{tabular}{|c|c|c|c|c|c|c|c|c|c|}
\hline \multirow{2}{*}{$\begin{array}{l}\text { Concentration } \\
\mu \mathrm{l} / 100 \mathrm{ml} \\
\text { medium }\end{array}$} & \multicolumn{3}{|c|}{ Final pH } & \multicolumn{3}{|c|}{$\begin{array}{l}\text { Average of mycelial } \\
\text { dry weight } \mathrm{mg} / 100 \mathrm{ml}\end{array}$} & \multicolumn{3}{|c|}{$\begin{array}{l}\text { Amount of aflatoxin } \\
\mu \mathrm{g} / 100 \mathrm{ml}\end{array}$} \\
\hline & Anise & Carawy & fennel & Anise & Carawy & fennel & Anise & Carawy & Fennel \\
\hline Control & 5.1 & 5.0 & 5.5 & 1.65 & 1.62 & 1.66 & 2000 & 1960 & 1960 \\
\hline 5 & 5.0 & 4.7 & 5.0 & 1.45 & 1.36 & 1.66 & 1700 & 1860 & 1660 \\
\hline 10 & 5.0 & 4.8 & 5.0 & 1.44 & 1.10 & 1.63 & 1540 & 1820 & 1600 \\
\hline 15 & 5.0 & 4.9 & 5.0 & 1.42 & 0.96 & 1.60 & 1500 & 1820 & 1560 \\
\hline 20 & 5.0 & 5.8 & 6.0 & 1.40 & 0.82 & 0.45 & 1400 & 1800 & 1300 \\
\hline 25 & 5.0 & 5.9 & 6.0 & 1.25 & 0.63 & 0.30 & 1360 & 1740 & 1000 \\
\hline 30 & 5.0 & 5.8 & 6.0 & 1.23 & 0.42 & 0.22 & 1300 & 1700 & 800 \\
\hline 35 & 5.0 & 6.0 & 5.0 & 1.30 & 0.38 & 0.18 & 800 & 1460 & 560 \\
\hline 40 & 5.0 & 6.0 & 5.0 & 1.23 & 0.36 & 0.09 & 560 & 1300 & 400 \\
\hline 50 & 5.0 & 5.0 & 5.0 & 1.18 & 0.12 & 0.03 & 160 & 1140 & 360 \\
\hline 100 & 5.2 & 5.0 & 5.0 & 1.00 & 0.09 & 0.01 & $\mathrm{ND}$ & $\mathrm{ND}$ & 200 \\
\hline 150 & $\begin{array}{l}\text { No. } \\
\text { growth }\end{array}$ & $\begin{array}{l}\text { No. } \\
\text { growth }\end{array}$ & $\begin{array}{l}\text { No. } \\
\text { growth }\end{array}$ & $\begin{array}{l}\text { No. } \\
\text { growth }\end{array}$ & $\begin{array}{l}\text { No. } \\
\text { growth }\end{array}$ & $\begin{array}{l}\text { No. } \\
\text { growth }\end{array}$ & $\mathrm{ND}$ & ND & $\mathrm{ND}$ \\
\hline 200 & $\begin{array}{l}\text { No. } \\
\text { growth }\end{array}$ & $\begin{array}{l}\text { No. } \\
\text { growth }\end{array}$ & $\begin{array}{l}\text { No. } \\
\text { growth }\end{array}$ & $\begin{array}{l}\text { No. } \\
\text { growth }\end{array}$ & $\begin{array}{c}\text { No. } \\
\text { growth }\end{array}$ & $\begin{array}{c}\text { No. } \\
\text { growth }\end{array}$ & $\mathrm{ND}$ & $\mathrm{ND}$ & $\mathrm{ND}$ \\
\hline
\end{tabular}

$\mathrm{ND}=$ Not Detected

Egypt. J. Microbiol. 50 (2015) 
Effect of Lactobacillus rahmnosus

Since LAB occur naturally in many food systems and they have been a part of the human diet for centuries, they can be regarded as safe organisms to consume. They have a great potential for extended use in biopreservation of both food and feed products. It would appear that lactic acid bacteria have the potential to be used as biological control agents in foods to prevent mould growth (Haskard et al., 2001). Data presented in Table 3 indicated that Lactobacillus rhamnosus inhibited both aflatoxin production by $100 \%$ after 7 days and the growth of $A$. flavus isolate No.66 by $60.76 \%$ after 14 days of incubation compared to the control. It was apparent that the anti-aflatoxigenic activity of L. rhamnosus decreased with prolongation of incubation periods. Our result in agreement with Bueno et al. (2006) mycelia dry weight of A. flavus was reduced to 73 and $85 \%$ by using L. casei CRL 431 and L. rhamnosus CRL 1224, respectively. Previous study also reported that L. rhamnosus was able to remove up to $80 \%$ of aflatoxinB from liquid media (El-Nezami et al., 1998). Moreover, the probiotic strain Lactobacillus rhamnosus strain GG (ATCC 53013) efficiently binds several mycotoxins, including aflatoxin $\mathrm{B}_{1}\left(\mathrm{AFB}_{1}\right)$ and aflatoxin $\mathrm{M}_{1}\left(\mathrm{AFM}_{1}\right)$, its hydroxylated metabolite, in vitro (El-Nezami et al.,1998; El-Nezami et al., 2000; Pierides et al., 2000 and El-Nezami et al., 2002). Lactobacillus strains could remove more $\mathrm{AFB}_{1}$ than Pediococcus and Leuconostoc strains. Five strains of $L$. rhamnosus, one strain of $L$. lactis and one strain of $L$. casei reduced $\mathrm{AFB}_{1}$ by more than $20 \%$. L. rhamnosus strain Lb50 reduced $\mathrm{AFB}_{1}$ by $45 \%$ (Zinedine et al., 2005). Bagherzadeh Kasmani et al. (2012) reported that L.rhamnosusTMU094 and L. fermentum were the most efficient species in AFB1 binding by 75.06 and $72.15 \%$, respectively.

TABLE 3. Effect of L. rhamnosus on aflatoxin production and growth of A. flavus isolate No. 66 (Both A.flavus and LAB were inoculated simultaneously) on (YES).

\begin{tabular}{|l|l|l|c|c|}
\hline \multirow{4}{*}{ Treatment } & $\begin{array}{l}\text { Incubation } \\
\text { in (days) }\end{array}$ & $\begin{array}{l}\text { Final } \\
\mathbf{p H}\end{array}$ & $\begin{array}{c}\text { Average of mycelial } \\
\mathbf{d r y} \text { weight } \\
(\mathbf{g} / \mathbf{1 0 0} \mathbf{m})\end{array}$ & $\begin{array}{c}\text { Amount of aflatoxin } \\
(\boldsymbol{\mu g} / \mathbf{1 0 0 m})\end{array}$ \\
\hline \multirow{4}{*}{$\begin{array}{l}\text { Control } \\
\text { (A.flavus) }\end{array}$} & 3 & 5.0 & 1.30 & 1820 \\
\cline { 2 - 5 } & 5 & 5.0 & 1.40 & 1920 \\
\cline { 2 - 5 } & 7 & 5.3 & 1.57 & 1980 \\
\cline { 2 - 5 } & 10 & 6.0 & 1.61 & 1700 \\
\hline \multirow{4}{*}{$\begin{array}{l}\text { Lb.rhamnosus } \\
\text { +(A.flavus) }\end{array}$} & 21 & 5.8 & 1.69 & 1560 \\
\cline { 2 - 5 } & 3 & 5.0 & 1.73 & 600 \\
\cline { 2 - 5 } & 5 & 5.0 & 1.21 & 100 \\
\cline { 2 - 5 } & 10 & 5.0 & 1.23 & $\mathrm{ND}$ \\
\cline { 2 - 5 } & 14 & 5.1 & 1.20 & 860 \\
\hline
\end{tabular}

The table expresses the final mycelial dry weight after subtraction the bacterial dry weight of cultures parallely cultivated under the same conditions. ND= Not Detected.

Egypt. J. Microbiol. 50 (2015) 
Effect of Lactobacillus rahmnosus, anise oil, and potassium sorbate on aflR gene expression

Data shown in Fig. 1 and 2 (all treatments 7 days age) show a high transcription level of aflR gene compared to control. The highest transcription level observed with potassium sorbate $4.0 \mu \mathrm{g} / 100 \mathrm{ml}$ medium at $\mathrm{pH}$ 6.0. In spite of aflR gene expressed no aflatoxin was detected in (YES) culture filtrates with these treatments. The basic assumption that determined the design of the experiment in this study was that aflR was the transcriptional regulator of the aflatoxin biosynthesis genes. If this was true, altered expression of aflR transcription should lead to altered transcription of the pathway genes. Further, if aflatoxin biosynthesis was regulated only by $a f l R$, altered transcription of aflR should lead to altered timing and accumulation of aflatoxin and production of aflatoxin under nonconductive conditions. This hypothesis was based on previous research showing that aflR is required for the transcription of the pathway genes nor-1 and ver-1 in A. flavus ( Payne et al., 1993) and that an additional copy of aflR in A. parasiticus leads to increased aflatoxin production and elevated transcript accumulation of nor-1, ver-1, and pksA (Chang et al., 1995). Additionally, Yu et al. (1996) showed that $A$. nidulans aflR was required for the transcription of the pathway genes leading to sterigmatocystin production. The present results indicate that aflR gene expression was found in all treatments. However, the treatments recorded (not detected) for $\mathrm{AFB}_{1}$ in (YES) culture filtrate. A transformant of A. parasiticus containing an extra copy of the aflR gene did not overcome the inhibitory effect of a high temperature on aflatoxin formation (Chang et al., 1995). Thus, although Liu \& Chu, (1998) suggest that a high temperature suppresses aflatoxin formation by down regulating $a f l R$, it is likely that, in addition to $a f l R$, another factor(s) may also play a critical role in the temperature-induced regulation of aflatoxin biosynthesis. Expression of aflR by real-time RT-PCR or RT-PCR was also detected in A. sojae strains, which have been proven nonaflatoxigenic and $A$. flavus strains, which did not produce aflatoxin. It was thought that the reason for the lack of expression of $a v n A$, $v b s$, ver $B$, and $o m t A$ genes was a lower transcription level of the regulatory gene, aflR. However, it was possible that translation was not performed even if aflR mRNA was expressed slightly or that aflR was degraded (Chang, 2004; Scherm et al., 2005 and Tominaga et al., 2006). A. flavus 194A strain was described as a "false positive" on the basis of the lack of any correlation between the gene(s) expression profile, as assessed by the multiplex RT-PCR and the aflatoxin production phenotype (Degola et al., 2007). Surprisingly enough, 16 AF biosynthesis genes analysed were readily transcribed in the 194A strain. However, non producers (Afla-) strains, in which most of the aflatoxin biosynthetic pathway is intact, have already been described (Ehrlich \& Cotty, 2004) and many events (mutations, post-transcriptional or post-translational events) that allowed gene transcription but not aflatoxin production might be envisaged. In addition, other genes not belonging to the aflatoxin gene cluster might directly or indirectly control toxin production, as reported for VeA and LexA in A. nidulans and A. parasiticus (Cary et al., 2006). O'Brian et al. (2007) reported that all the aflatoxin biosynthetic genes were much more highly expressed at $28{ }^{\circ} \mathrm{C}$ relative to $37^{\circ} \mathrm{C}$. To our surprise expression of the pathway regulatory genes $a f l R$ and aflS, as well as aflR antisense, did not differ between the two temperatures. These data indicate that the failure of $A$. flavus to produce aflatoxin at $37^{\circ} \mathrm{C}$ is not due to lack of

Egypt. J. Microbiol. 50 (2015) 
transcription of aflR or aflS. One explanation is that aflR is nonfunctional at high temperatures. However, Watson et al. (1999) and Matsushima et al. (2001) revealed that the lack of a functional aflR was insufficient to explain the complete repression of aflRs and other aflatoxin related genes in A. sojae. The lack of aflatoxin production by A. sojae can be attributed, at least in part, to the premature termination defect in aflRs, which deletes the $\mathrm{C}$ - terminal transcription of aflatoxin activation domain that was critical for expression of aflatoxin biosynthetic genes (Takahashi et al., 2002). Adjacent to the aflR gene in the aflatoxin gene cluster, aflS, a divergently transcribed gene, has been shown to be responsible of enhanced transcription of other genes in the cluster through its interaction with aflR, though its exact function was still unclear (Chang, 2003 and Yu \& Keller, 2005). Clustered biosynthetic genes for fungal secondary metabolism were not only regulated by specific transcription factors, as a global epigenetic control mechanism might be conducted by genes, beyond the biosynthetic cluster, which were able to regulate multiple physiological processes and the response to environmental and nutritional factors such as temperature, $\mathrm{pH}$, light, carbon and nitrogen sources (Georgianna \& Payne, 2009). Accinelli et al. (2008) analyzed expression of five AF genes ( $a f l D$, aflG, aflP, aflR, and aflS ) by RT-PCR. They did not find a correlation between gene expression profiles of aflatoxigenic $A$. flavus isolates and $\mathrm{AFB}_{1}$ concentrations in the soil. Moreover, Jamali et al. (2013) purpose that a significant reduction in the expression of aflR gene in curcuminexposed A.parasiticus is responsible in part not only for AFB1 inhibition by the fungus, but also for down regulating other genes studied. In contrast, Kong et al. (2010) reported that the mRNA abundances of aflR and aflS genes in control were $1.11 \pm 0.24$ and $0.18 \pm 0.05$, respectively, while in experiment group were $0.28 \pm 0.03$ and $0.024 \pm 0.005$, respectively indicating that Bacillus megaterium could suppress the expression of these two genes. The concentration of aflatoxins and the mRNA abundances of these two genes in the control experiment corresponded: the lower the expression of aflR gene and aflS gene, the lower the aflatoxin concentration detected. In addition, Sweeney et al. (2000) demonstrated that aflatoxin production monitored by thin layer chromatography was correlated with transcription of aflR and aflQ in $A$. parasiticus strain 439. Prieto et al. (1996) and Woloshuk et al. (1995) showed that aflR was sufficient to initiate gene transcription of early, mid, and late genes in the pathway, and that AflS enhances the transcription of early and mid aflatoxin pathway genes. Another possible explanation was that regulation of AF cluster gene expression was complex, and factors other than transcript levels of aflR and aflS were important in its regulation. afls transcript was thought to be dependent on aflR (Du et al., 2007; Ehrlich et al., 1999b and Price et al., 2006).The expression of the majority aflatoxin biosynthetic genes including aflR and aflS of all strains varied with regarded to the aflatoxin-producing ability and the growth conditions (Scherm et al., 2005). In addition, the possibility exists that some of the genes involved in aflatoxin and ST biosynthesis were located somewhere outside the gene clusters. The genetic control of aflatoxin biosynthesis in relation to primary metabolism and environmental stimuli was apparently beyond this defined gene cluster (Calvo et al., 2002; Feng \& Leonard, 1998; Flaherty \& Payne, 1997 and Yu et al., 2002). Flaherty \& Payne (1997) concluded that transcriptional activation of the pathway was not the only requirement for the initiation of aflatoxin biosynthesis. The mechanism of this regulation was not known, but it was provided two lines of evidence that it was mediated through fungal metabolism. Under normal conditions, transcription of the pathway required specific Egypt. J. Microbiol. 50 (2015) 
conducive conditions, for example, the presence of simple sugars. If the regulation of pathway transcription was bypassed by the constitutive transcription of aflR, the induction profile for aflatoxin was the same as in wild-type strains. This argues that additional medium-dependent factors were required for initiation of aflatoxin biosynthesis. The second line of evidence was the addition of a single compound affects the biosynthesis of aflatoxin, and we now known that it was not at the level of aflR transcription. Several studies were suggested that the physiology of the fungus played an important role in the regulation of aflatoxin biosynthesis (Buchanan et al., 1987; Buchanan \& Stahl, 1984 and Shih \& Marth, 1974). Recent evidence for the complex regulation by media was supported by the observation in A. niger that intracellular cyclic AMP levels were associated with the initial sucrose levels in the media (Gradisnik-Grapulin \& Legisa, 1997). Thus the regulation of aflatoxin biosynthesis was more complicated than previously considered and did not solely involve the transcription activation of the pathway. Identification of all of the genes and global regulators involved in and related to aflatoxin biosynthesis in the fungal system is a daunting challenge. A. flavus genomics and microarray technologies ( $\mathrm{Yu}$ et al., 2002 and O'Brian et al., 2003) will provide a new avenue for deciphering such mechanisms and unraveling these regulatory elements governing aflatoxin biosynthesis.

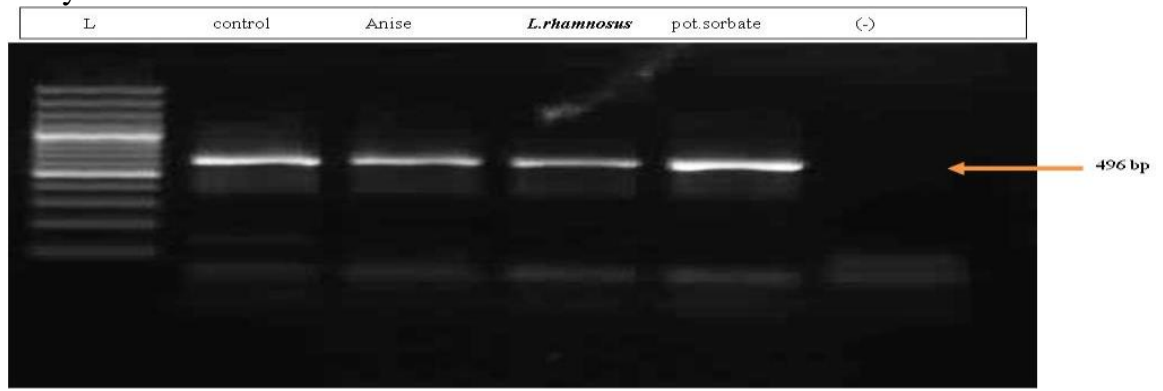

Fig.1. Agarose gel electrophoresis of GAPDH gene transcript during incubation of $L$. rahmnosus, anise oil, and potassium sorbate with $A$. flavus as indused by real time - q PCR.

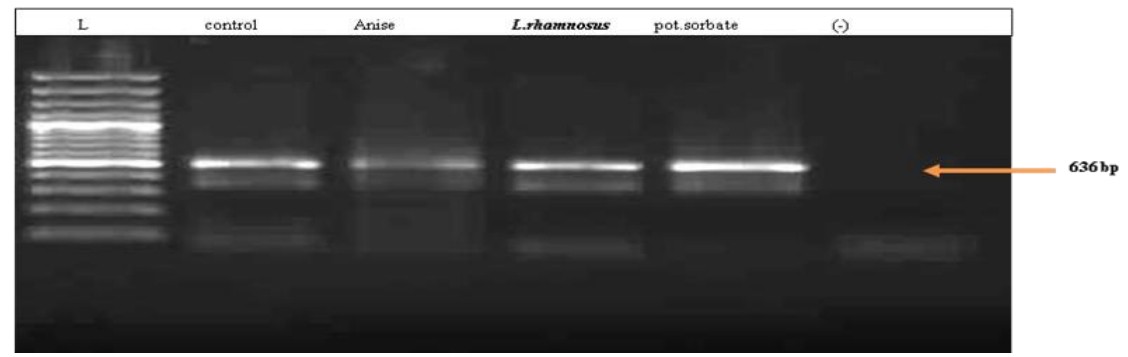

Fig.2. Agarose gel electrophoresis of aflR gene transcript during incubation of $L$. rahmnosus, anise oil, and potassium sorbate with $A$. flavus as indused by real time - q PCR.

Control $=$ mycelium of $A$. flavus harvested after 3 days of incubation at $30^{\circ} \mathrm{C}$.

$(-)$ = Negative control (contains all components for real time-q PCR except the sample).

$\mathrm{L}=100: 3000 \mathrm{bp}$ standards 
There is no relation between the growth of A. flavus and production of aflatoxins in spite of the presence of aflR gene in some strains of Aspergillus which not secretes aflatoxins $i$. e., A. sojae used in Japanese foods. These results agreed with the results of Jorgensen (2007) who reported that mold strain belong to the species A. oryzae, A. sojae are highly valued as Koji molds in the traditional preparation of fermented foods and as protein production hosts in modern industrial processes. As close relatives of aflatoxin-producing wild molds, koji molds possess an aflatoxin gene homolog cluster. Some strains identified as A. oryzae and A. sojae have been implicated in aflatoxin production. Identification of a strain as A. oryzae or A. sojae is no guarantee of its inability to produce aflatoxins or other toxic metabolites. Toxigenic potential must be determined specifically for individual strains. The species taxa, A. oryzae and $A$. sojae, are currently conserved by societal issues.

Clustered biosynthetic genes for fungal secondary metabolism were not only regulated by specific transcription factors, as a global epigenetic control mechanism might be conducted by genes, beyond the biosynthetic cluster, which were able to regulate multiple physiological processes and the response to environmental and nutritional factors such as temperature, $\mathrm{pH}$, light, carbon and nitrogen sources (Georgianna \& Payne, 2009).

\section{Conclusion}

The high anti-fungitoxic and antifungal effect exhibited by EO in the present study strengthens its utilization as an ideal antimicrobial for food preservation compared to the traditional chemical preservatives. L.rhamnosus has great potential biocontrol activity against the decay and aflatoxin biosynthesis caused by A.flavus. This potential may extend to use as a natural biopreservatives of both food and feed products. Our results obtained from real time-q PCR technique for aflR gene expression indicated that it was inappropriate method for diagnosis non-aflatoxin producing strains or vise viscera. Further genetic studies are needed to evaluate the role of each genes internal and external $\mathrm{AF}$ biosynthesis cluster genes during different phases of A. flavus development and aflatoxin biosynthesis and different detoxification treatments.

Acknowledgments: I am greatly thankful to director of Biotechnology Lab. (FARP) Cairo University for being so kind, helpful, and for providing facilities to complete this work.

\section{References}

Accinelli, C., Abbas, H.K., Zablotowicz, R.M. and Wilkinson, J.P.( 2008) A. flavus isolates and AFB1 concentrations in the soil. Canadian Journal Microbiology, 54(5), 371-379.

Agar, G., Alpsoy, L. and Yildirim, N. (2005) The protective role of selenium against the genotoxicity induced by aflatoxin B1 in root cells of crop plants. Fresenius Environmental Bulletin, 14, 849-853.

Egypt. J. Microbiol. 50 (2015) 
Alpsoy, L. (2010) Inhibitory effect of essential oil on aflatoxin activities. African Journal of Biotechnology, 9(17), 2474-2481.

Alpsoy, L., Yildirim, A. and Agar, G. (2009) The antioxidant effects of vitamin A, C and $\mathrm{E}$ on aflatoxin B1 induced oxidative stress in human lymphocytes. Toxicology and Industrial Health, 25(2), 121-127.

AOAC (Analytical Official Assaying Chemistry) (1995) "International Analysis of Aflatoxins", chapter 49. Arlington, $16^{\text {th }}$ ed. Washington, D.C. ISNB: 09355845449780935584547.

AOAC (2003) "Determination of Aflatoxins in Corn and Peanut Butter Using HPLC". Association Official of Analytical Chemistry - International Official Methods of Analysis, $17^{\text {th }}$ ed , chapter, 49.2.17, Current Through Revision \# 2, 2003.

Bagherzadeh Kasmani, F., Karimi Torshizi, M. A., Allameh, A. A. and Shariatmadari, F. (2012) Aflatoxin detoxification potential of lactic acid bacteria isolated from Iranian poultry. Iranian Journal of Veterinary Research, Shiraz University, 13(2), 152-155.

Bhatnagar, D., Ehrlich , K. C. and Cleveland, T. E. (2003) Molecular genetic analysis and regulation of aflatoxin biosynthesis. Applied Microbiology and Biotechnology, $\mathbf{6 1}$ 83-93.

Bhatnagar, D., Cary, J.W., Ehrlich, K., Yu, J. and Cleveland, T.E. (2006) Understanding the genetics of regulation of aflatoxin production and Aspergillus flavus development. Mycopathologia, 162(3), 155-166.

Bluma, R., Amaiden, M.R. and Etcheverry, M. (2008) Screening of Argentine plant extracts: Impact on growth parameters and aflatoxin B1 accumulation by Aspergillus section Flavi. International Journal of Food Microbiology, 122(1-2), 114-125.

Bluma, R. and Etcheverry, M. (2008) Application of essential oils in maize grain: Impact on Aspergillus section Flavi growth parameters and aflatoxin accumulation. Food Microbiology, 25, 324-334.

Brul, S. and Coote, P. (1999) Preservative agents in foods: Mode of action and microbial resistance mechanisms. International Journal of Food Microbiology, 50 (1-2), 1-17.

Buchanan, R. L., Jones, S. B., Gerasimowicz, W. V., Zaika, L. L., Stahl, H. G. and Ocker, L. A. (1987) Regulation of aflatoxin biosynthesis: Assessment of the role of cellular energy status as a regulator of the induction of aflatoxin production. Applied and Environmental Microbiology, 53(6), 1227-1231.

Buchanan, R.L. and Stahl, H.G. (1984) Caffeine inhibition of aflatoxin synthesis: Probable site of action. Applied and Environmental Microbiology, 47(6),1193-2000.

Bueno, D. J., Casale, C. H. , Pizzolitto, R. P., Salano, M. A. and Olivier G. (2006) Physical adsorption of aflatoxin $\mathrm{B}_{1}$ by lactic acid and Saccharomyces cerevisiae: A theoretical model. Journal of Food Protection, 70(9), 2148-2154.

Bueno, D.J. , Silva, J.O., Oliver, G. and González , S.N. (2006) Lactobacillus casei CRL 431 and Lactobacillus rhamnosus CRL 1224 as biological controls for Aspergillus flavus strains. Journal of Food Protection, 69(10), 2544-2548.

Egypt. J. Microbiol. 50 (2015) 
Bullerman, L., Lieu, B. and Sieier, A. (1977) Inhibition of growth and aflatoxin production by cinnamon and clove oils, cinnamic aldehyde and eugenol. Journal of Food Science, 45(4), 1107-1109.

Calvo, A. M., Wilson, A. R., Bok, J. W. and Keller, N. P. (2002) Relationship between secondary metabolism and fungal development. Microbiology and Molecular Biology Reviews, 66(3), 447-459.

Calvo, A.M., Wilson, R.A., Bok, J.W. and Keller, N.P. (2002) Relationship between secondary metabolism and fungal development. Microbiology and Moleculay Biology Reviews, 66(3), 447-459.

Carr, E. G., Dunlap, G., Horner, R. H., Koegel, R. L., Turnbull, A. P., Sailor, W. Anderson, J. L., Albin, R. W., Koegel , L. K. and Fox, L. (2002) Positive behavior support: Evolution of an applied science. Journal of Positive Behavior Intervention, 4(1), 4-16.

Cary, J. W., Ehrlich, K. C. , Wright, M., Chang, P.K. and Bhatnagar, D. (2000) Generation of aflR disruption mutants of Aspergillus parasiticus. Applied Microbiology and Biotechnology, 53(6),680-684.

Cary, J. W., Ehrlich, K. C., Kale, S. P., Calvo, A. M., Bhatnagar, D. and Cleveland , T. E. (2006) Regulatory elements in aflatoxin biosynthesis. Mycotoxin Research, 22(2), 105-109.

Cavaleiro, C., Pinto, E., Gonçalves, M. J. and Salgueiro, L. (2006) Antifungal activity of Juniperus essential oils against dermatophytes, Aspergillus and Candida strains. Journal of Applied Microbiology, 100 (5), 1333-1338.

Chang, P.K. (2004) Lack of interaction between aflR and aflJ contributes to nonaflatoxigenicity of Aspergillus sojae. Journal of Biotechnology, 107(3), 145-253.

Chang, P.K. (2003) The Aspergillus parasiticus protein AFLJ interacts with the aflatoxin pathway specific regulator aflR. Molecular Genetics and Genomics , 268(6),711-719.

Chang, P-K., Cary, J. W., Yu, J., Bhatnagar, D. and Cleveland T. E. (1995) The Aspergillus parasiticus polyketide synthase gene, pksA, a homolog of Aspergillus nidulans wA, is required for aflatoxin B1. Molecular and General Genetics, 248(3), 270-277.

Chomczynski, P. and Sacchi N. (1987) Single-step method of RNA isolation by acid guanidiniumthiocyanatephenol-chloroform extraction. Analytical Biochemistry , 162,156-159.

Dal Bello, F., Dal Bello,C. I. and Clarke, L.A. (2007) Improvement of the quality and self life of wheat bread by fermentation with the antifungal strain Lactobacillus plantarum FSI 1.7. Journal of Cereal Science, 45, 309-318Davise, H. 1993. "Medically Important Fungi: A Guide to identification". American Society for Microbiology, USA 54, 179-181.

Degola, F., Berni, E., Dall'Asta, C., Spotti, E., Marchelli, R., Ferrero, I. and Restivo, F.M. (2007) A multiplex RT-PCR approach to detect aflatoxigenic strains of Aspergillus flavus. Journal of Applied Microbiology, 103(2), 409-417.

Egypt. J. Microbiol. 50 (2015) 
Druvefors, U.A., Passoth, V. and Schnurer, J. (2005) Nutrient effects on biocontrol of Penicillium roqueforti by Pichia anomala J121 during airtight storage of wheat. Applied Environmental Microbiology, 71(14), 1865-1869.

Du, W., O'Brian, G. R. and Payne, G. A. (2007) Function and regulation of aflJ in the accumulation of aflatoxin early pathway intermediate in Aspergillus flavus. Food Additive and Contaminants, 24(10), 1043-1050.

Dutton, M. F. (1988) Enzymes and aflatoxin biosynthesis. Microbiology Reviews, 52, 274-295.

Ehrlich, K. C. and Cotty, P. J. (2004) An isolate of A. flavus used to reduce aflatoxin contamination in cotton seed has a defective polyketide synthase gene. Applied Microbiology and Biotechnology, 65(4), 473-478.

Ehrlich, K. C., Montalbano, B. G. and Cary J. W. (1999a) Characterization of the promoter for the gene encoding the aflatoxin biosynthetic pathway regulatory protein aflR. Biochimica et Biophysica Acta (BBA) - Gene Structure and Expression , 1444(3), 412-417.

Ehrlich, K. C., Montalbano, B. G. and Cary, J. W. (1999) aflR, to the promoters of aflatoxin pathway biosynthesis genes in Aspergillus parasiticus. Genetics, 230, 249257.

El-Nezami, H. S., Kankaanpää, P.E., Salminen S. and Ahokas, J.T. (1998a) Ability of dairy strains of lactic acid bacteria to bind food carcinogens. Food and Chemical Toxicology, 36(4), 321-326.

El-Nezami, H., Polychronaki, N., Salminen, S. and Mykkänen, H. (2002) Binding rather than metabolism may explain the interaction of two foodgrade Lactobacillus strains with zearalenone and its derivative $\alpha$-Zearalenol. Applied and Environmental Microbiology, 68(7), 3545-3549.

El-Nezami, H., Mykkanen, H., Kankaanpaa, P., Salminen, S. and Ahokas. J. (2000) Ability of Lactobacillus and Propionibacterium strains to remove aflatoxin B from the chicken duodenum. Journal of Food Protection, 63(2), 549-552.

Farag, R., Daw, Z. and Abo-Raya, S. (1989) Influence of some spice essential oils on $A$. parasiticus growth and production of aflatoxins in a synthetic medium. Journal of Food Science, 54(1), 74-76.

Feng, G. H. and Leonard,T. J. (1998) Culture conditions control expression of the genes for aflatoxin and sterigmatocystin biosynthesis in Aspergillus parasiticus and A. nidulans. Applied and Environmental Microbiology, 64(6), 2275-2277.

Flaherty, J. E. and Payne, G. A. (1997) Overexpression of aflR leads to upregulation of pathway gene transcription and increased aflatoxin production in Aspergillus flavus. Applied and Environmental Microbiology, 63(10), 3995-4000.

Georgianna, D. R. and Payne, G. A. (2009) Genetic regulation of aflatoxin biosynthesis: From gene to genome. Fungal Genetics and Biology, 46(2), 113-125. 
Gong, Y., Hounsa, A., Egal, S. , Turner, P.C., Sutcliffe, A.E. and Hall, A.J. (2004) Post weaning exposure to aflatoxin results in impaired child growth: A longitudinal study in Benin, West Africa. Environmental Health Perspective, 112(13), 1334-1338.

Gourama, H. and Bullerman, L.B. (1995b) Inhibition of growth and aflatoxin production of Aspergillus flavus and Lactobacillus species. Journal of Food Protection, 58(11) , 1249- 1256.

Gradisnik-Grapulin, M. and Legisa, M. (1997) A spontaneous change in the intracellular cyclic AMP level in Aspergillus niger is influenced by sucrose concentration in the medium and by light. Applied and Environmental Microbiology, 63(7), 2844-2849.

Gratz, S., Täubel, M., Juvonen, R. O., Viluksela, M., Turner, P. C. , Mykkänen, H. and El-Nezami, H. (2006) Lactobacillus rhamnosus strain GG modulates intestinal absorption, fecal excretion, and toxicity of aflatoxin B1in rats. Applied and Environmental Microbiology, 72(11), 7398-7400.

Gray, J. and Bemiller, J. (2003) Bread staling: Molecular basis and control. Comprehensive Reviews in Food Science and Safety, 2(1), 1-21.

Guynot, M. E., Ramos, A. J., Sala, D., Sanchis, V. and Marín, S. (2002) Combined effects of weak acid preservatives, $\mathrm{pH}$ and water activity on growth of Eurotium species on a sponge cake. International Journal of Food Microbiology, 76(1-2), 39-46.

Guynot, M. E., Ramos, A. J., Sanchis, V. and Marín, S. (2004) Study of benzoate, propionate, and sorbate salts as mould spoilage inhibitors on intermediate moisture bakery products of low pH (4.5-5.5). International Journal of Food Microbiology, 101(2)161-168.

Hasan, H.A.H. (1994) Inhibition of mycoflora and zearalenone on rice by selected essential oils. Pakistan Journal of Scientific and Industrial Research, 37(11), 471-473.

Haskard, C., El-Nezami, H., Kankaanää, P., Salminen, S. and Ahokas, J. (2001) Surface binding of aflatoxin $\mathrm{B}_{1}$ by lactic acid bacteria. Applied and Environmental Microbiology, 67(7), 3086-3091.

Hsieh, D. (1988) Potential human health hazards of mycotoxins. In: Natori S, Hashimoto K, Ueno Y (Ed.). "Mycotoxins and Phytotoxins. Third Joint Food and Agriculture Organization". W.H.O./ United Nations Environment Program International Conference of 9234 Afr. J. Biotechnol. Mycotoxins. Elsevier, Amsterdam, The Netherlands. p. 69-80.

Jamali, M., Karimipour, M., Shams-Ghahfarokhi, M., Amani A. and RazzaghiAbyaneh, M. (2013) Expression of aflatoxin genes aflO (omtB) and aflQ (ordA) differentiates levels of aflatoxin production by Aspergillus flavus strains from soils of pistachio orchards, Research in Microbiology,164(4), 293-299.

Jorgensen, T.R. (2007) Identification and toxigenic potential of industrial important fungi, Aspergillus oryzae, A. sojae. J. Food Prot. 70 (12), 2916 - 2934.

Klich,M.A., (2002) Identification of common Aspergillus species. Cetraalbureauvoor Schimmelcultures, Utrecht, The Netherlands.

Egypt. J. Microbiol. 50 (2015) 
Koehler, P. E., Hanlin, R. T. and Beraha, L. (1975) Production of aflatoxins B1 and G1 by Aspergillus flavus and Aspergillus parasiticus isolated from market pecans. Applied Micobiology, 30(4) , 581-583.

Kong, Q., Shan, S., Liu, Q., Wang, X. and Yu, F. (2010) Biocontrol of Aspergillus flavus on peanut kernels by use of a strain of marine Bacillus megaterium. International Journal of Food Microbiology, 139(1-2), 31-35.

Krebs, H. A., Wiggins, D., Stubbs, M., Sols, A. and Bedoya F. (1983) Studies on the mechanism of the antifungal action of benzoate. Biochemical Journal, 214 (3), 657 663.

Krishnamurthy, Y.L. and Shashikala, J. (2006) Inhibition of aflatoxin $B_{1}$ production of Aspergillus flavus, isolated from soybean seeds by certain natural plant products. Letters in Applied Microbiolog, 43 (5), 469-474.

Kumar, A., Shukla, R., Singh, P., Prasad, C. S. and Dubey N. K. (2008)Assessment of Thymus vulgaris L. essential oil as a safe botanical preservative against post harvest fungal infestation of food commodities. Innovative Food Science and Emerging Technologies, 9(4), 575-580.

Kumar, R., Mishra, A. K., Dubey, N. K. and Tripathi, Y. B. (2007) Evaluation of Chenopodium ambrosioides oil as a potential source of antifungal, antiaflatoxigenic and antioxidant activity. International Journal of Food Microbiology, 115(2), $159-164$.

Lis-Balch, M., Ochoka, R.J., Deans, S.G., Asztemborska, M. and Hart, S. (1999) Difference in bioactivity between the enantiomers of $\alpha$-pipene. Journal of Essential Oil Research, 11,393-397.

Liu, B. H. and Chu, F. S. (1998) Regulation if aflR and its product, ALFR, associated with aflatoxin biosynthesis. Applied and Environmental Microbiology, 64(10), 3718-3723.

López-Malo, A., Alzamora, S. M., Palou, E. and Maris, S. (2005) Aspergillus flavus growth in the presence of chemical preservatives and naturally occurring antimicrobial compound. International Journal of Food Microbiology, 99(2), 119-128.

Lück, E. (1981) Conservación Química de los Alimentos., Ed. Acribia, Zaragoza, España, 238pp.

Magnusson, J., Ström, K., Roos, S., Sjögren, J. and Schürer, J. (2003) Broad and complex antifungal activity among environmental isolates of lactic acid bacteria. FEMS Microbiology Letters, 219, 129-135.

Marín, S., Guynot, M. E., Neira, P., Bernadó, M., Sanchis, V. and Ramos, A.J. (2002a) Risk assessment of the use of sub-optimal levels of weak-acid preservatives in the control of mould growth on bakery products. International Journal of Food Microbiology, 79(3), 203-211.

Marín, S., Guynot, M. E., Sanchis, V., Arbonés, J. and Ramos, A. J. (2002b) Aspergillus flavus, Aspergillus niger and Penicillium corylophilum spoilage prevention of bakery products by means of weak-acid preservatives. Journal of Food Science, 67(6), 2271-2277.

Egypt. J. Microbiol. 50 (2015) 
Matsushima, K., Yahiro, K., Hanya, Y., Abe, K., Yabe, K. and Hamasaki, T. (2001) Absence of aflatoxin biosynthesis in Koji mold (Aspergillus soja). Applied Microbiology and Biotechnology, 55(6), 771-776.

Moubasher, A.H. (1993) For soil fungi in Qatar and other Arab countries. Centre for Scientific and Applied Research, University of Qatar. ISNB: 999212025, 9789992121023.

Nychas, G.J.E. (1995) Natural antimicrobial from plants In: "New Methods of Food Preservations". (Blackie Academic and Professional London) edited by G.W. Gould: pp. $58-89$

O'Brian, G. R., Georgianna, D. R. , Wilkinson, J. R., Yu, J., Abbas, H. K., Bhatnagar, D., Cleveland, T. E., Nierman, W. and Payne , G. A. (2007) The effect of elevated temperature on gene transcription and aflatoxin biosynthesis. Mycologia, 99(2), 232-239.

O'Brian, G.R., Fakhoury, A.M. and Payne, G.A. (2003) Identification of genes differentially expressed during aflatoxin biosynthesis in Aspergillus flavus and Aspergillus parasiticus. Fungal Genetics and Biology, 39(2), 118-127.

Pandey, R. (2003) Pesticide and sterility. Everyman's Science, XXXVIII, 38, 84-86.

Paster, N., Menasherov, M., Ravid, U. and Juven, B. (1995) Antifungal activity of oregano and thyme essential oils applied as fumigants against fungi attacking stored grain. Journal of Food Protection, 58(1), 81-85.

Pawar, V. C. and Thaker, V. S. (2007) In vitro efficacy of 75 essential oils against Aspergillus niger. Mycoses, 49(4), 316-323.

Payne, G.A., Nystrom, G.J., Bhatnagar (1993)

Pierides, M., El-Nezami, H. Peltonen, K. Salminen, S. and Ahokas, J. (2000) Ability of dairy strains of lactic acid bacteria to bind aflatoxin $\mathrm{M}_{1}$ in a food model. Journal of Food Protection, 63(5), 645-650.

Pina-Vaz, C., Rodrigues, A. G., Pinto, E., Costa-de-Oliveira, S., Tavares, C. and Salgueiro, L. R. (2004) Antifungal activity of thymus oils and their major compounds. Journal of the European Academy of Dermatology and Venereology, 18(1), 73-78.

Polychronaki, N., Wild, C. P., Mykkanen, H. , Amra, H., Abdel-Wahhab, M. , Sylla, A., Diallo, M., El-Nezami, H. and Turner, P. C. (2008)Urinary biomarkers of aflatoxin exposure in young children from Egypt and Guinea. Food and Chemical Toxicology, 46(2), 519-526.

Price, M.S., Yu , J., Nierman, W.C., Kim, H.S., Pritchard, B., Jacobus, C.A., Bhatnagar, D., Cleveland, T.E. and Payne, G.A. (2006) The aflatoxin pathway regulator aflR induces gene transcription inside and outside of the aflatoxin biosynthetic cluster. FEMS Microbiolog Letters, 255(2), 275-279. 
Prieto, R., Yousibova, G. L. and Woloshuk, C. P. (1996) Identification of aflatoxin biosynthesis genes by genetic complementation in an Aspergillus flavus mutant lacking the aflatoxin gene cluster. Applied and Environmental Microbiology, 62(10), 3567-3571.

Raper, J.P. and Fennell, D.T. (1965) "The Genus Aspergillus" . Williams and Wilkins. Baltimorr, U.S.A.

Rasoli, I. and Owlia, P. (2005) Chemoprevention by thyme oils of Aspergillus parasiticus growth and aflatoxin production. Phytochem. 66(24), 2851-2856.

Rosengaus, R. B., Lefebvre, M. L. and Traniello, J. F. A. (2000) Inhibition of fungal spore germination by Nasutitermes: Evidence for a possible antiseptic role of soldier defensive secretions. Journal of Chemical Ecology, 26(1), 21-39.

Samson, R.A. (2000) List of names of Trichocomaceae published between 1992 and 1999. In: "Integration of Modern Taxonomic Methods for Penicillium and Aspergillus Classification". Samson R.A., Pitt J.I. (Ed.). pp. 73-79, Amsterdam.The Netherlands: Harwood Academic Publishers; ISBN: 90-5823-159-3.

Scherm, B., Palombab, M., Serra, D., Marcelloa, A. and Migheli, Q. (2005) Detection of transcripts of the aflatoxin genes aflD, aflO, and aflP by reverse transcriptionpolymerase chain reaction allows differentiation of aflatoxin-producing and nonproducing isolates of Aspergillus flavus and Aspergillus parasiticus. International Journal of Food Microbiology, 98(2), 201-210.

Shih, C. N. and Marth, E. H. (1974) Aflatoxin formation, lipid synhesis, and glucose metabolism by Aspergillus parasiticus during incubation with and without agitation. Biochimica et Biophysica Acta (BBA) - General Subjects, 338(1), 286-296.

Singh, K., Frisbad, J.C., Thrane, U. and Mathur, S.B. (1991) An illustrated manual on identification of some seed-borne Aspergilli,Fusaria, Penicillia and their mycotoxins. Danish Government. Insitute of Seed Pathology for Developing Countries, Hellerup 8, 12.ISNB8770263175, 9788770263177

Smith-palmer, A., Stewart, J. and Fyfe, L. (2001) The potential application of plant essential oils as natural food preservatives in soft cheese. Food Microbiology, 18(4), 463-470.

Soliman, K. M. and Badeaa R. I. (2002) Effect of oil extracts from some medicinal plants on different mycotoxigenic fungi.

Stiles, M. E. (1996) Biopreservation by lactic acid bacteria. Antonie Van Leeuwenhoek, 70 (2-4), 331-345.

Sweeney, M. J., Pamies, P. and Dobson, A. D. W. (2000) The use of reverse transcription-polymerase chain reaction (RT-PCR) for monitoring aflatoxin production in Aspergillus parasiticus 439. International Journal of Food Microbiology, 56(1), 97- 103.

Takahashi, T., Chang, P. K., Matsushima, K., Yu, J., Abe, K., Bhatnagar, D., Cleveland, Y. and Koyama, T. E. (2002) Nonfunctionality of Aspergillus sojae aflR in a strain of Aspergillus parasiticus with a disrupted aflR gene. Applied and Environmental Microbiology,68(8), 3737-3743. 
Tominaga, M., Lee, Y.H., Hayashi, R., Suzuki, Y., Yamada, O., Sakamoto, K., Gotoh, K. and Akita, O. (2006) Molecular analysis of an inactive aflatoxin biosynthesis gene cluster in Aspergillus oryzae RIB strains. Applied and Environmental Microbiology, 72(1), 484-490.

Tsugane, S. (2004) Dietary factor and cancer risk-evidence from epidemiological studies. Gan To Kagaku Ryoho, 31(6), 847-852.

Tuley De Silva, K. (1995) "A Manual of Essential Oils Industry". United Nations Lndustrlal Development Organization, Vienna, Austria.

Ueno, Y. (Ed.), "Mycotoxins and Phytotoxins". Third Joint Food and Agriculture Organization/W.H.O./United Nations E? Program International Conference of Mycotoxins. Elsevier, Amsterdam, The Netherlands.

Varma, S. K. and Verma, R. A. B. (1987) Aflatoxin B1 production in orange (Citrus reticulata) juice by isolates of Aspergillus flavus Link. Mycopathologia, 97(2), 101-104.

Watson, A. J., Fuller, L. J., Jeens, D. J. and Archer, D. B. (1999) Homologys of aflatoxin biosynthesis genes and sequence of aflR in Aspergillus oryzae and Aspergillus sojae. Applied and Environmental Microbiology, 65(1), 307-310.

Webster, R. P., Gawde, M. D. and Bhattacharya, R. K. (1996) Effect of different vitamin A status on carcinogen-induced DNA damage and repair enzymes in rats. In Vivo, 10 (1), 113-118.

Wiame, I., Remy, S., Swennen, R. and Sági, L. (2000) Irreversible heat inactivation of DNaseI without RNA degradation. BioTechniques, 29, 252-256.

Woloshuk, C. P., Foutz, K. R., Brewer, J. F., Bhatnagar, D. , Cleveland, T. E. and Payne, G. A. (1994) Molecular characterization of aflR, a regulatory locus for aflatoxin biosynthesis. Applied and Environmental Microbiology, 60(7), 2408-2414.

Woloshuk, C.P., Yousibova, G.L., Rollins, J.A., Bhatnagar, D. and Payne, G.A. (1995) Molecular characterization of the afl-1 locus in Aspergillus flavus. Applied and Environmental Microbiology, 61(8), 3019-3023.

Yabe, K. and Nakajima, H. (2004) Enzyme reactions and genes in aflatoxin biosynthesis. Applied Microbiology and Biotechnology, 64,745-755.

Yu, J. H. and Keller, N. P. (2005) Regulation of secondary metabolism in filamentous fungi. Annual Review of Phytopathology, 43, 437-458.

Yu, J., Bhatnagar, D. and Cleveland, T. E. (2002) Aspergillus flavus genomics for elimination of aflatoxin contamination. Mycopathologia, 155,10.

Yu, J., Butchko, R. A., Fernandes, M., Keller, N. P., Leonard, T. J. and Adams, T. H. (1996) Conservation of structure and function of the aflatoxin regulatory gene aflR from Aspergillus nidulans and A. flavus. Current Genetics, 29, 549-555.

Yu, J., Butchko, R. A., Fernandes, M., Keller, N. P., Leonard, T. J. and Adams, T. H. (1996) Conservation of structure and function of the aflatoxin regulatory gene aflR from Aspergillus nidulans and A. flavus. Current Genetics, 29(6), 549-555.

Egypt. J. Microbiol. 50 (2015) 
Yu, J., Chang, P. K., Ehrlich, K. C., Cary, J. W., Bhatnagar, D., Cleveland, T. E. , Payne, G. A., Linz, J. E., Woloshuk, C. P. and Bennett, J. W. (2004) Clustered pathway genes in aflatoxin biosynthesis. Applied and Environmental Microbiology, 70(3), 1253-1262.

Yu, J., Cleveland, T. E., Nierman, W.C. and Bennett, J.W. (2005) Aspergillus flavus genomics: Gateway to human and animal health, food safety, and crop resistance to diseases. Revista Iberoamericana de Micología, 22(4), 194-202.

Yu, J., Bhatnagar, D. Cleveland, T. E. and W. Nierman, C. (2002) Aspergillus flavus EST technology and its applications for eliminating aflatoxin contamination. Mycopathologia, 155(1-2),6.

Zinedine, A., Faid, M. and Benlemlih, M. (2005) In vitro reduction of aflatoxin B1 by lactic acid bacteria isolated from morroccan sourdough bread. International Journal of Agriculture and Biology, 7(1), 67-70.

(Received 15/6/2015; accecpted $2 / 8 / 2015$ 


\section{تثبيط انتاج الافلاتوكسين بواسطة الزيوت الطبيعية و L.rhamnosus والاكتثاف الجزيئي للتخليق الحيوي للافلاتوكسين لجين aflR في}

\section{A. flavus فطرالجناف}

$$
\begin{aligned}
& \text { "طلعت ابراهيم السيد و ايمان حافظ الدريدي }
\end{aligned}
$$

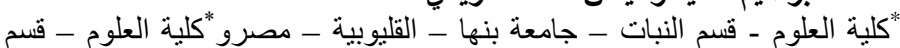

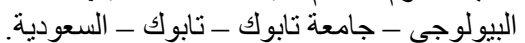

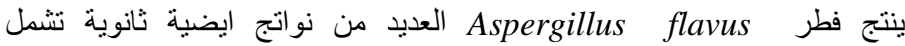
الافلاتوكسين B1 الاكثر سمية واكفر المركبات المسبية للسرطان و الملوثة للاغذية و الاعلاف الافكين

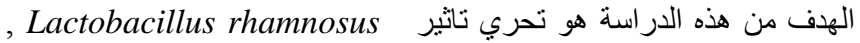

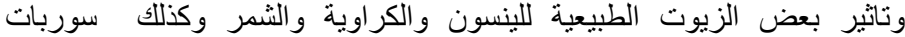

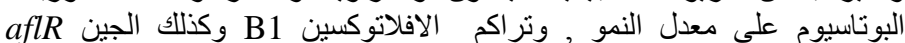

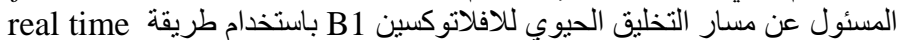
- q PCR

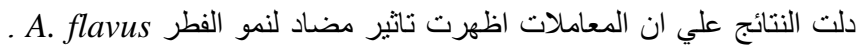
Le rhamnosus

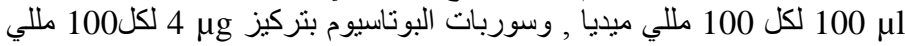

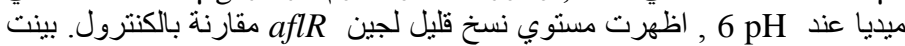

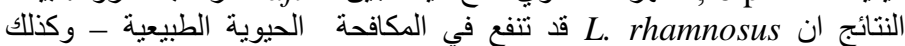
استخدام الينسون كمضاد ميكروبي مثالي ضد في الند 